\title{
The usage of enzyme in ultrasound-assisted enzymatic extraction method and its effect on yield extract from Keji Beling (Strobilanthes crispus.) leaves
}

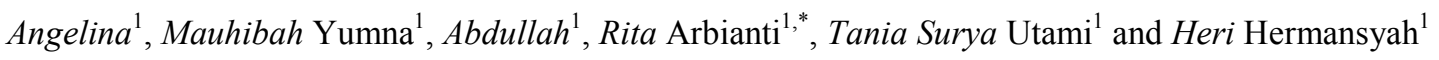 \\ ${ }^{1}$ Department of Chemical Engineering, Faculty of Engineering, Universitas Indonesia, Depok 16424, Indonesia
}

\begin{abstract}
Green extraction process is a method which is used to obtain various plant extracts with minimum impact on the environment. Green extraction will reduce energy consumption, allow use of alternative solvents and renewable natural products, and ensure a safe and high quality extract. Ultrasound-assisted enzymatic extraction (UAEE) is one of green extraction method. UAEE is a mild, efficient and environmental friendly extraction method and it has been adopted for extracting various kinds of compounds. The use of enzyme will catalyze hydrolysis of the cytoderm and glycoproteins, therefore enhancing the release of bioactive substances by disrupting plant cells. The optimum extraction conditions with a maximum yield extract of $48.63 \%$ are as follows: the concentration of ethanol is $50 \%$ and the amount of added enzyme is $70 \mathrm{mg} / \mathrm{g}$. Crude extract from keji beling leaves is tested using Gas Chromatography and Mass Spectrometry (GC-MS) to identify components that have anti-hypercholesterolemic activity, which are hexadecanoic acid, octadecanoic acid and demethyl squalene.
\end{abstract}

\section{Introduction}

Ultrasound-Assisted Enzymatic Extraction (UAEE) method is a new extraction technology that has many advantages such as increasing the extraction yield and physiological activity of extracts of various plants [1]. The use of enzymes in UAEE may increase the effect of pre-treatment solvent and minimize the amount of solvent required for the extraction, reduces extraction time and improve the yield of the compound to be extracted [2]. The enzyme is used to degrade the cell walls of plants and increases the permeability of cell walls. The destruction of the plant cell wall causes the easy extraction of active compounds that improve the yield of extraction of the active compound [3].

Hypercholesterolemia is a condition of increasing the concentration of cholesterol in the blood that exceeds normal value. Excess cholesterol have been shown to disrupt and change the structure of the blood vessels which results in impaired endothelial function that causes lesions, plaques, occlusion, and embolism. It is also thought to be responsible for increased oxidative stress [4]. One of the compounds that can inhibit the intestinal absorption of cholesterol to lower blood cholesterol levels in humans is phytosterols [5].

Phytosterols is a competitive inhibitor that inhibits HMG-CoA reductase enzyme to inhibit the absorption of cholesterol. The test of inhibition of the enzyme HMGCoA Reductase aims to measure the effectiveness of phytosterol compounds in the absorption of cholesterol.
The release profile and inhibition percentage of the extracts of Keji Beling leaves, it can be concluded that Keji Beling leaf extract can lower cholesterol levels in the blood [6]. Keji beling leaves contain chemical compounds including phytosterols that has antihypercholesterolemic activity [7].

In this research, the optimum condition of cellulase enzyme concentration and concentration of ethanol as solvent are determined to obtain the highest yield extract of Keji Beling leaves. Furthermore, quantitative analysis is conducted to find compounds that have antihypercholesterolemic activity besides phytosterols and SEM analysis is used to analyze the effectiveness of using UAEE methods based on the morphology of Keji Beling leaves.

\section{Methodology}

\subsection{Materials}

The dried leaves of Strobilanthes crispus were collected from Semarang, Indonesia. Cellulase "Onozuka" RS was purchased from Yakult Pharmaceutical Ind. Co., Ltd.

\subsection{UAEE of Keji Beling leaves}

The UAEE method consists of 2 main steps, which are enzymatic hydrolysis and sonication. $10 \mathrm{~g}$ of the prepared samples was soaked with $0.3 \mathrm{mg}$ cellulase

Corresponding author: arbianti@che.ui.ac.id 
enzyme in a $100 \mathrm{~mL}$ aquadest and citrate buffer was used to adjust $\mathrm{pH}$. This solution is stirred at a low velocity. The enzymatic hydrolysis was conducted at a constant temperature and $\mathrm{pH}$ for several hours. The extraction process was designed with these corresponding conditions. Using the following conditions of $30 \mathrm{mg} / \mathrm{g}$ cellulase, $50 \%$ ethanol, a mesh size of $\leq 0.585 \mathrm{~mm}, 2 \mathrm{~h}$ of enzymatic hydrolysis at $\mathrm{pH} 4$ 6 , a liquid-solid ratio of 20:1, 60 min of sonication time and $30{ }^{\circ} \mathrm{C}$ extraction temperature, the extraction yield from the Keji Beling leaves was determined. Each of the parameters was kept as above while the others were varied as follows: cellulase concentrations $(0,30,50,70$ and $90 \mathrm{mg} / \mathrm{g})$ and ethanol concentrations $(30,40,50,60$ and $70 \%)$.

\subsection{Quantitative test of the crude extract}

Quantitative test is used to analyze the concentration of compounds that have anti-hypercholesterolemic activity by using GC-MS method.

\section{Results and Discussion}

\subsection{Enzymatic hydrolysis and ultrasound extraction of Keji Beling leaves}

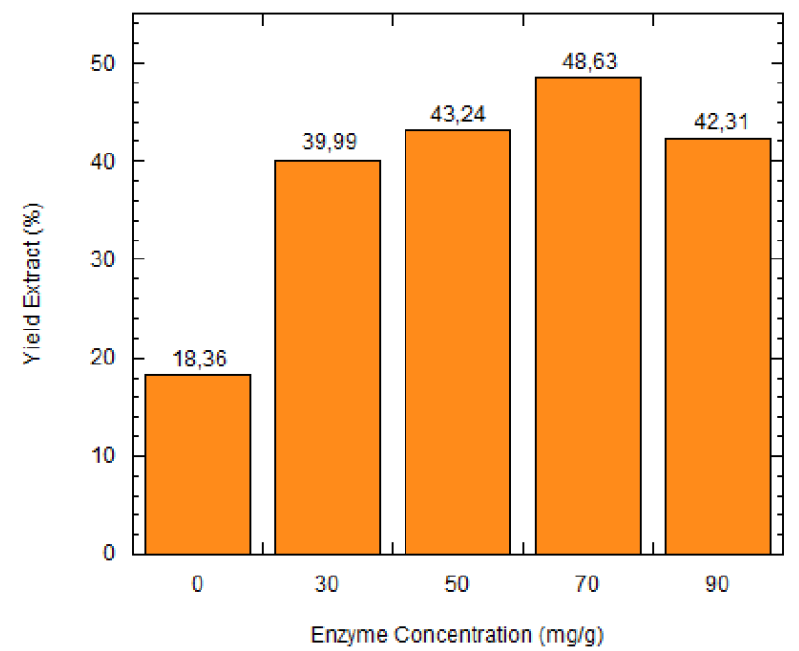

Figure 1. Variations of enzyme concentration (Enzymatic hydrolysis time $2 \mathrm{~h}$; Ethanol concentration $50 \%$ )

From Figure 1, it can be seen that when there is an increase in the concentration of the enzyme used, the extraction of the resulting yield will also increase up to a certain point where it can no longer increase. By increasing the concentration of the enzyme, the reaction rate will also increase as more molecules of enzyme that will collide with the substrate molecule. The reaction rate will also be increased with increasing concentrations of the substrate. If the enzyme is used too much it will not be effective to perform the enzymatic reaction because at a certain concentration, the enzyme will become saturated and increased concentration would not have had any effect on the reaction rate of product formation because the substrate is not a limiting factor [8].
In addition to the enzyme concentration, $\mathrm{pH}$ also affects the extraction yield. An enzyme is a protein that has a biochemical activity as a catalyst for the reaction. Working as a protein enzyme is affected by the level of $\mathrm{pH}$ conditions. Optimal activity of an enzyme depends on the $\mathrm{pH}$ conditions, the optimum $\mathrm{pH}$ conditions will assist the enzyme in catalyzing a reaction well. Cellulase enzymes used in this study has the optimum $\mathrm{pH}$ of 4-6 [9], so in this study, the $\mathrm{pH}$ was maintained around 4-6 so that the enzyme will work at optimum conditions [10].

In this study, the concentration of the enzyme indirectly affect the yield of extraction, wherein the extraction yield increases with increasing enzyme concentration until reaching the saturation point, which is at a concentration of $70 \mathrm{mg} / \mathrm{g}$. Once past the saturation point, the concentration of the enzyme did not improve the extraction yield again.

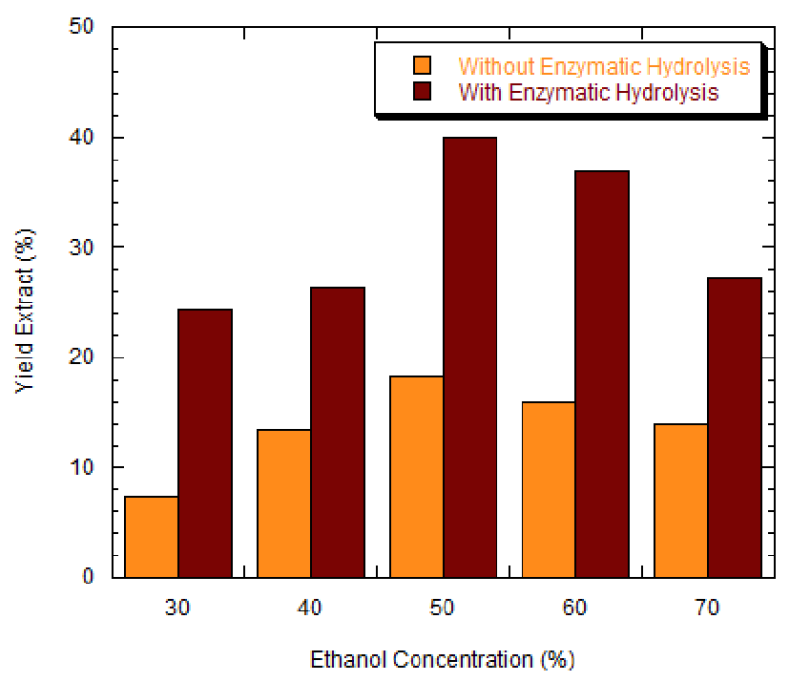

Figure 2. Variations of ethanol concentration (Enzyme concentration $30 \mathrm{mg} / \mathrm{g}$; Enzymatic hydrolysis time 2h)

From Figure 2, it can be seen that the concentration of $50 \%$ ethanol is the most optimum yield the highest extraction yield. In addition, the process of enzymatic hydrolysis using cellulase enzymes increase the yield of crude extract obtained in each variation of the concentration of ethanol. Thus, it can be seen that pretreatment process or enzymatic hydrolysis is a very important stage of the process which may affect the acquisition of extraction yield. Therefore, when the ethanol concentration reaches the right proportion, the total yield of extraction will reach a maximum value. This is consistent to the experimental results without and after hydrolysis enzymatic hydrolysis. Results from the study showed that the optimum concentration of ethanol to extract phytosterols from the sample is $50 \%$.

The usage of ethanol in the extraction will show a color change that does not damage the components of the leaves. This is evidenced by the use of ethanol in the extraction, the leaves change color does not remain green or brown leaves. When compared to using a higher water concentration, which shows dark blackish brown color, the color of the leaves change color of the solution due to degradation due to high temperatures. In addition, 
the use of solvent water is not efficient in terms of time, because the extraction cycle takes a long time [11].

When the ethanol concentration reaches the right proportion, the total yield of extraction will reach a maximum value. This is consistent to the experimental results without and after enzymatic hydrolysis. Results from the study showed that the optimum concentration of ethanol to extract phytosterols from the sample is $50 \%$. In this study, the optimum yield extraction obtained from Keji Beling leaves is $48.63 \%$, with the optimum condition of enzyme concentration is $70 \mathrm{mg} / \mathrm{g}$ and ethanol concentration is $50 \%$.

\subsection{Morphology determination using SEM}

SEM is used to observe the microscopic physical changes from the initial leaf samples, the samples treated leaves after enzymatic hydrolysis and after the extraction of sonication. The treatment given to the substrate with cellulase enzymes used for the degradation of cellulose structure, lowering the degree of crystallinity of the cellulose and improve the enzymatic hydrolysis of cellulose [13].

(a)

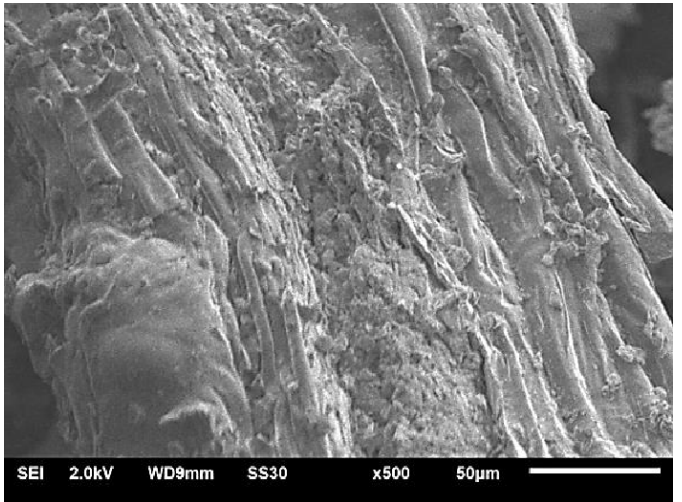

(b)

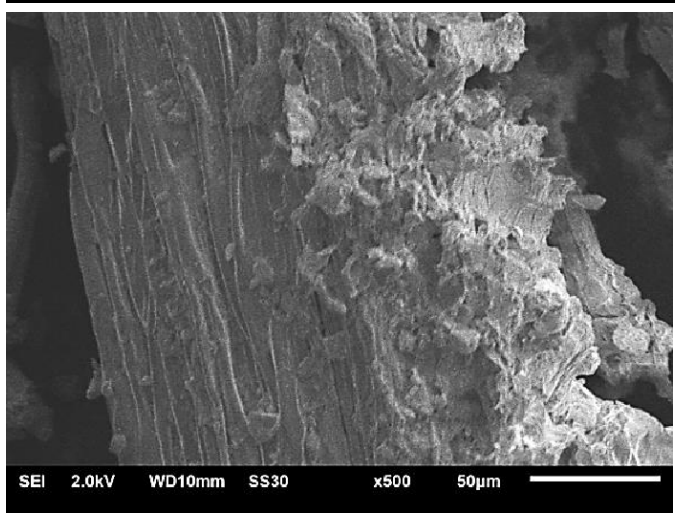

(c)

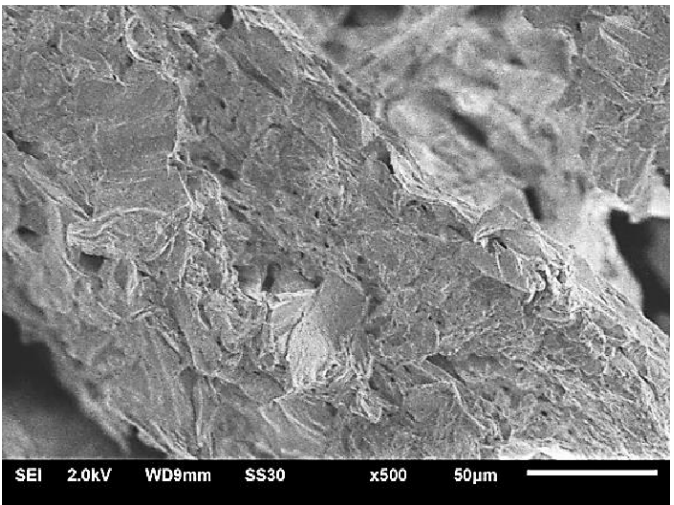

(d)

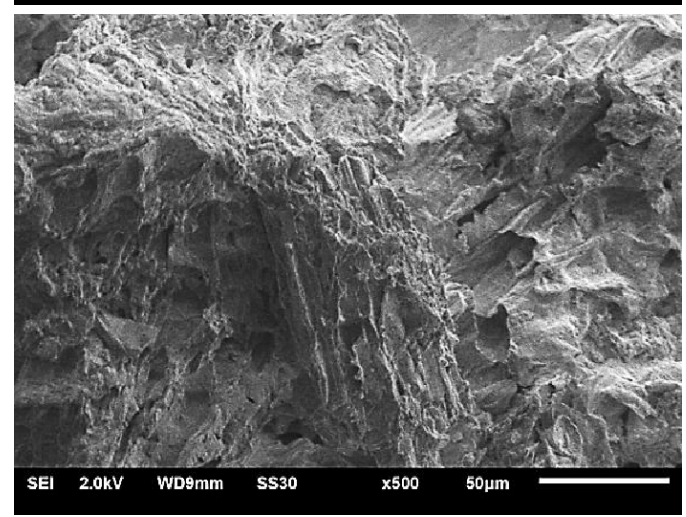

Figure 3. Morphology of Keji Beling leaves with 500 times magnification when (a) Without any preliminary treatment (b) After extraction with help of ultrasonication (c) After enzymatic hydrolysis (d) After enzymatic hydrolysis followed by ultrasonication

Figure 3(a) shows the structure of the initial leaf samples that have not received any treatment. The visible surface of the leaf sample is still intact and only slightly torn, usually caused by the process of milling to shrink the size of the leaves [12]. Milling is done to get the size of about $0.585 \mathrm{~mm}$ leaves a physical pretreatment. Milling served to increase the area of contact and porosity thus expected to increase the effectiveness of pre-treatment and hydrolysis process [12].

Leaf samples showed different patterns after being treated with enzymes or sonication. By using sonication with ethanol and water, leaf samples receive heat treatment and vibration, the internal surface of leaf increasingly torn and broken (see Figure 3(b)). In the pre-treatment by sonication causes changes in the chemical composition of the leaves because of the role of vibration can damage the bond in lignin and cellulose and then dissolving the active substance. The treatment effects have been reported for pre-treatment of water in bamboo by sonication [12].

Effect of enzymatic hydrolysis pre-treatment on samples of leaves can also cause fiber development, the cell lumen diameter enlargement and thinning of the cell walls as a form of dissolved cellulose of the cell wall ${ }^{[12]}$. The holes and the destruction of the cell wall surface contained in the leaf structure after pre-treatment of the enzyme (Figure 3(c)) indicating the possibility of degradation of hemicellulose in addition to cellulose degradation, as a result of destruction of cellulose and hemicellulose bonds that began to occur ${ }^{[12]}$, It is 
expected that with the destruction of leaf fibers with an enzyme pre-treatment will cause the cellulose structure is exposed, making them easier to react directly with the enzyme in the hydrolysis reaction. With the help of enzymes to damage the structure of cellulose, the resulting crude extract is expected to be more.

Merging the use of enzymes and sonication also aims to increase the extraction yield, to minimize the effect on the environment, such as use of solvents, which are less and also the efficiency of the extraction time. Merging these two methods have given excellent results in the extraction of active substances from plants ${ }^{[14]}$. It is also evident from the results of this study, which can be seen that the use of enzymes increase the extraction yield generated. This can be caused by damage to the structure of plants caused many active substances that can be extracted and dissolved in the solvent used ${ }^{[14]}$. From Figure 3(d), it can be seen that the structure of Keji Beling leaves are more destroyed than the other images. This supports the hypothesis that the incorporation of the $\mathrm{UAE}$ and EAE method is better in the degradation of plant cell wall, thus also increasing the extraction yield.

\subsection{Quantitative analysis using GC-MS}

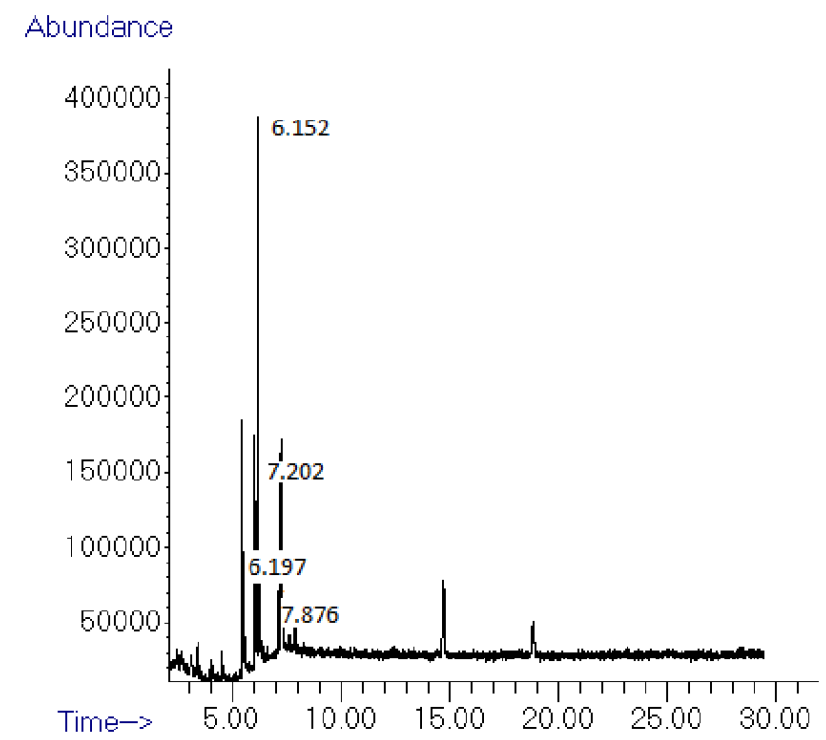

Figure 4. GC-MS chromatogram of crude extract from Keji Beling leaves

Based on the identification of compounds found in the crude extract of Keji Beling leaves using GC-MS, compounds that have anti-hypercholesterolemic activity is hexadecanoic acid, octadecanoic acid, and squalene. These compounds are found in the retention time of 6.152, 7.202 and 7.876 min respectively (see Figure 4). Anti-hypercholesterolemic activity demonstrates the ability of a compound to reduce blood cholesterol ${ }^{[15]}$. Squalene itself is an important precursor in the synthesis of phytosterol and precursors for such triterpenoids lupeol, amyrin and betulin ${ }^{[16]}$.

A research conducted by Aini (2015) ${ }^{[6]}$ demonstrated the ability of extracts of Keji Beling leaves to inhibit the enzyme HMG-CoA Reductase (HMGR). In these studies, no quantitative test phytosterol contained in the crude extract of Keji Beling leaves produced, but only use a qualitative test Liebermann-Burchard reagent. The resulting color change was seen the same as has been done in this study.

The results of the study Aini (2015) ${ }^{[6]}$, the positive control (Atorvastatin) with a concentration of $10 \mathrm{ppm}$ is used has a power of inhibition by $44.2 \%$ while the percentage of inhibition of Keji Beling leaves extract against the positive control concentration varies in the range of $15 \%$ to $17.83 \%$. From these studies, it is known that extracts of Keji Beling leaves potential in inhibiting HMGR enzyme that plays a role in cholesterol synthesis pathway. HMGR enzyme inhibition by Keji Beling leaves extracts is expected to lower cholesterol levels in the blood.

\section{Conclusion}

Based on the results of the research, it can be concluded that the optimum conditions are as follows: the amount of added enzyme is $70 \mathrm{mg} / \mathrm{g}$ and the concentration of ethanol is $50 \%$. Under these optimum extraction conditions, the maximum yield extract obtained from Keji Beling leaves is $48.63 \%$.

The authors gratefully acknowledge Universitas Indonesia for PITTA Research Grant 2018 and Department of Chemical Engineering for supporting this research

\section{References}

1. Chemat, F., Vian, MA and Cravotto, G. Green Extraction of Natural Products: Concept and Principles. International journal of molecular sciences, 13 (7), pp.8615-8627 (2012)

2. Meyer, US. Enzyme Technology For Precision Functional Food Ingredient Processes. Annals of the New York Academy of Sciences, 1190 (1), pp.126-132 (2010)

3. Puri, M., Sharma, D. and Barrow, CJ. Enzymeassisted Extraction of Bioactives from Plants. Trends in Biotechnology, 30 (1), pp.37-44 (2012)

4. Stapleton, PA., Goodwill, AG., James ME., Brock, RW., Frisbee, JC. Hypercholesterolemia and Microvascular Dysfunction: Interventional Strategies. Journal Of Inflamation, pp. 1-10 (2010)

5. Carr, TP, Ash, MM \& Brown, AW. Cholesterollowering phytosterols: factors affecting Reviews their use and efficacy. Nutrition and Dietary Supplements. pp. 59-72 (2010)

6. Aini, Desna Qurratul. Uji Inhibisi dan Profil Pelepasan Nanopartikel Ekstrak Daun Keji Beling (Strobilanthes crispus) untuk Seidaan Obat Antihiperkolesterolemia. Skripsi. Depok: Fakultas Teknik Universitas Indonesia (2015)

7. Pratiwi, Fransiska Milaniati. Nanoenkapsulasi Ekstrak Daun Keji Beling (Strobilanthes crispus) dengan Metode Gelasi Ionik untuk Sediaan Obat Antihiperkolesterolemia. Skripsi. Depok: Fakultas Teknik Universitas Indonesia (2014) 
8. Michaelis, L. and ML Menten. Die kinetic der invertinwirkung. Biochem. Z. 49: 333-369 (1913)

9. Okada, G. Methods Enzymol. 160, 259-263 (1988)

10. Huang, D., Zhou, X., Si, J., Gong, X., Wang, S. Studies on cellulase-ultrasonic assisted extraction technology for flavonoids from Illicium verum residues. Chemistry Central Journal 10:56 (2016)

11. Winarno. Kimia Pangan dan Gizi. Pt. Gramedia Pustaka Utama. Jakarta (2004)

12. Fajriutami, T., Fatriasari, W., and Hermiati, E. Pengaruh Pra Perlakuan Basa Pada Ampas Tebu Terhadap Karakterisasi Pulp Dan Produksi Gula Pereduksi. Jurnal Riset Industri Vol. 10 No. 3 (2016)

13. Sun, Y., Cheng, J. Hydrolysis of lignocellulosic materials for ethanol production: a review. Bioresource Technology, 83:1-11 (2002)

14. Xu, DP, Zheng, J., Zhou, Y., Li, Y., Li, S. and Li, HB, Ultrasound-assisted Extraction of Natural Antioxidants from the Flower of Limonium sinuatum: Optimization and Comparison with Conventional Methods, Food chemistry, 217, pp.552-559 (2017)

15. V. Anand Gideon. GC-MS analysis of phytochemical components of Pseudoglochidion anamalayanum Gamble: An endangered medicinal tree. Asian Journal of Plant Science and Research, 5 (12): 36-41 (2015)

16. Cheong, BE, Zakaria, NA, Cheng, AYF and Teoh, PL. GC-MS Analysis of Strobilanthes crispus Plants and Callus. Transactions on Science and Technology, 3 (1-2), pp.155-161 (2016) 